\title{
EFEKTIVITAS MEDIA SAKURA (SUSUN HURUF, SUKU KATA, DAN KATA) BERBASIS MULTISENSORI UNTUK MENINGKATKAN KEMAMPUAN MEMBACA BAGI ANAK DISLEKSIA DI SEKOLAH DASAR
}

\author{
Siska Nursara, Nurul Hidayati Rofiah \\ Universitas Ahmad Dahlan \\ siska1400005206@webmail.uad.ac.id
}

\begin{abstract}
The purpose of this study was to examine the effectiveness of multisensory-based SAKURA media. The research method used was a single subject type experimental method with the $A-B-A$ research design. The instrument used was a matter of dyslexic children's reading ability test. The subject in this study was a dyslexic child in Sempu Public Elementary School. Data analysis techniques used are descriptive statistics, analysis of conditions, and analysis of conditions. Based on the results of research and discussion, it can be concluded that SAKURA media is effective in increasing the reading ability of GAS subjects. This can be proven by an increase in the percentage of subject achievement at the time of the intervention. In this study, subjects (GAS) got mean levels increasing from 75.2 under baseline 1 (A1) to 88.9 under intervention (B), and 99.3 under baseline 2 (A2). A low percentage of overlap supports this. The percentage overlap between baseline one condition and intervention conditions is $0 \%$, and intervention conditions with baseline 2 are $0 \%$.
\end{abstract}

Keywords: Dyslexia, Media SAKURA, Multisensory

\begin{abstract}
ABSTRAK
Tujuan dari penelitian ini untuk menguji efektivitas media SAKURA berbasis multisensori. Metode penelitian yang digunakan adalah metode eksperimen jenis subjek tunggal dengan desain penelitian A-B-A. Instrumen yang digunakan adalah soal tes kemampuan membaca anak disleksia. Subjek dalam penelitian ini yaitu seorang anak disleksia di SD Negeri Sempu. Teknik analisis data yang digunakan adalah statistik deskriptif, analisis dalam kondisi, dan analisis antar kondisi. Berdasarkan hasil penelitian dan pembahasan dapat disimpulkan bahwa media SAKURA efektif meningkatkan kemampuan membaca subjek GAS. Hal ini dapat dibuktikan dengan adanya peningkatan persentase ketercapaian subjek pada saat intervensi. Pada penelitian ini subjek (GAS) mendapatkan mean level meningkat dari 75,2 pada kondisi baseline 1 (A1) menjadi 88,9 pada kondisi intervensi (B), dan 99,3 pada kondisi baseline 2 (A2). Hal ini didukung dengan persentase overlap yang rendah. Persentase overlap antar kondisi baseline 1 dan kondisi intervensi yaitu 0\% dan kondisi intervensi dengan baseline 2 yaitu $0 \%$.
\end{abstract}

Kata kunci: Disleksia,Media SAKURA, Multisensori

\section{PENDAHULUAN}

Pada awal sekolah ditingkat sekolah dasar, guru akan dihadapkan pada permasalahan membaca siswa. Setiap siswa merupakan individu yang berbeda, begitupun dengan 
kemampuan membaca yang dimiliki setiap siswa juga akan berbeda-beda. Siswa yang mendapatkan masalah dengan membaca akan mengalami kesulitan dalam pembelajaran di sekolah. Sejalan dengan itu, Wood, dkk (2014:67) menjelaskan, bahwa kesulitan membaca memengaruhi segala aspek kehidupan seseorang sejak awal masuk sekolah. Hal ini dimulai ketika anak belajar membaca ditingkat awal sekolah, hingga bertahun-tahun kemudian saat anak diharuskan membaca untuk mempelajari sesuatu yang lebih spesifik.

Kesulitan membaca yang dialami anak juga akan berdampak pada kesulitan menulis, kondisi ini sering disebut dengan disleksia. Child Develoment Institute dalam Jamaris (2015:139) menjelaskan, bahwa disleksia adalah keadaan yang berkaitan dengan kemampuan membaca yang sangat tidak memuaskan. Individu yang mengalami disleksia memiliki IQ rata-rata (normal) bahkan di atas rata-rata, akan tetapi memiliki kemampuan membaca 1 atau 11/2 tingkat di bawah IQ-nya. Akan tetapi, berdasarkan hasil observasi dan wawancara dengan guru kelas di SD Negeri Sempu, terdapat anak kelas 2 yang memiliki kesamaan dengan ciri-ciri anak disleksia dengan masalah yang mengikutinya seperti masalah fonologi, masalah mengingat perkataan, masalah penyusunan yang sistematis atau berurut, serta masalah ingatan jangka pendek, serta. Namun, belum dilakukan asessment sehingga tidak diketahui secara jelas anak tersebut disleksia atau slow learner atau kesulitan belajar yang lain. Lebih lanjut, Mulyadi (2010:154) menyimpulkan bahwa disleksia merupakan kesulitan membaca, mengeja, menulis serta kesulitan dalam mengartikan atau mengenali struktur kata yang memberikan efek terhadap proses belajar. Berdasarkan beberapa pengertian di atas, maka dapat disimpulkan bahwa disleksia adalah kesulitan membaca dalam hal mengeja, membaca, mengenali struktur kata bahkan menulis yang tidak ada hubungannya dengan IQ.

Jamaris (2015:139) menjelaskan "kasus dyslexia ditemui antara 3\%-6\% dari jumlah penduduk. Namun, kasus yang berkaitan dengan kesulitan membaca yang tidak digolongkan ke dalam dyslexia ditemui lebih dari 50\% dari jumlah penduduk." Sehingga, seorang anak yang mengalami disleksia akan memberikan efek terhadap kemampuan membaca dan menulis. Lebih lanjut, (Jamaris, 2015:140) menjelaskan ciri-ciri siswa yang mengalami disleksia, seperti : (1) membaca secara terbalik tulisan yang dibaca seperti: duku dibaca kudu, d dibaca b, atau p dibaca q, (2) menuliskan huruf secara terbalik, (3) mengalami kesulitan dalam menyebutkan kembali informasi yang diberikan secara lisan, (4) kualitas tulisan buruk, karakter huruf yang ditulis tidak jelas, (5) sulit dalam mengikuti perintah yang diberikan secara lisan, (6) mengalami kesulitan dalam mengenal bentuk huruf dan mengucapkan bunyu huruf, (7) mengalami kesulitan dalam menggabungkan bunyi huruf menjadi kata yang berarti, serta (8) sangat lambat dalam membaca karena kesulitan dalam mengenal huruf, mengingat bunyi huruf dan menggabungkan bunyi huruf menjadi kata yang berarti.

Lerner dalam Abdurrahman (2012:157) menjelaskan, bahwa kemampuan membaca digunakan sebagai dasar untuk menguasai berbagai bidang studi. Jika pada anak usia sekolah permulaan tidak segera memiliki kemampuan membaca, maka akan mengalami banyak kesulitan dalam mempelajari berbagai bidang studi pada kelas-kelas berikutnya. Oleh karena itu, anak harus belajar membaca agar dapat menguasai berbagai bidang studi. Sedangkan, Mercer dalam Abdurrahman (2012:158) menjelaskan, bahwa kemampuan membaca tidak hanya meningkatkan keterampilan kerja dan penguasaan berbagai bidang akademik, akan tetapi juga memungkinkan berpartisipasi dalam kehidupan sosial-budaya, politik, dan memenuhi kebutuhan emosional. Mengingat banyaknya manfaat kemampuan membaca, maka anak harus belajar membaca agar ia dapat membaca untuk belajar.

Ada beberapa metode pengajaran membaca bagi anak disleksia, salah satunya adalah metode multisensori. "Model yang dikembangkan dalam penelitian ini adalah 
metode multisensori yang bertujuan untuk mengembangkan kemampuan membaca anak disleksia ... metode multisensori yang merupakan metode yang melibatkan seluruh sensori dalam mempelajari huruf, suku kata dan kata" (Praptiningrum, 2009).

Sadiman (2014:6) mengemukakan, bahwa media merupakan segala sesuatu yang dapat digunakan untuk menyampaikan pesan dari pengirim ke penerima sehingga dapat merangsang minat, perhatian, perasaan, dan pikiran seseorang. Sedangkan, Rossi \& Breidle dalam Sanjaya (2015:204) mengemukakan, bahwa media pembelajaran adalah seluruh alat dan bahan yang dapat digunakan untuk tujuan pendidikan, seperti buku, koran, majalah, radio, televisi, dan sebagainya. Berdasarkan uraian di atas, dapat ditarik kesimpulan bahwa anak yang berkebutuhan khusus maupun tidak berkebutuhan khusus memerlukan media dalam proses belajar mengajar. Terutama untuk anak disleksia media diperlukan sebagai perantara atau pengantar pesan.

Rofiah \& Sukma (2017) mengembangkan media SAKURA (susun huruf, suku kata dan kata) berbasis multisensori untuk meningkatkan kemampuan membaca anak disleksia. Keunggulan media SAKURA yang dikembangkan yakni melatih fungsi semua sensoris yang dimiliki anak untuk mengenal stau mempelajari sesuatu. Melatih sensoris anak dengan memegang secara langsung benda yang akan dipelajari anak membantu daya ingat anak disleksia. Selain itu, juga dapat meningkatkan kemampuan membaca anak. Sehingga, peneliti disini akan meneliti efektivitas media SAKURA (susun huruf. Suku kata, dan kata) berbasis multisensori untuk meningkatkan kemampuan membaca anak disleksia. Media SAKURA berbasis multisensori yang telah dikembangkan ini, belum dilakukan uji efektivitas penggunaan untuk meningkatkan kemampuan membaca anak disleksia.

Berdasarkan latar belakang di atas, maka dapat dirumuskan masalah dalam penelitian ini sebagai berikut : Apakah penggunaan media SAKURA berbasis multisensori efektif untuk meningkatkan kemampuan membaca bagi anak disleksia? Sedangkan, tujuan penelitian ini adalah mengetahui efektivitas media SAKURA berbasis multisensori untuk meningkatkan kemampuan membaca bagi anak disleksia.

\section{METODE PENELITIAN}

Penelitian ini menggunakan metode eksperimen jenis subjek tunggal atau Single Subject Research (SSR) dengan desain A-B-A yang bertujuan untuk mengetahui efektivitas penggunaan media SAKURA yang diberikan kepada subjek secara berulangulang pada waktu tertentu dalam rangka meningkatkan kemampuan membaca bagi anak disleksia. Sunanto, Takeuchi, \& Nakata (2005:59) menjelaskan "desain A-B-A merupakan pengembangan dari desain dasar A-B, desain A-B-A ini telah menunjukkan adanya hubungan sebab akibat antara variabel terikat dan variabel bebas."

Penelitian dilaksanakan di salah satu SD Inklusi di Sleman yakni SD N Sempu. Pemilihan tempat tersebut diharapkan dapat menjawab permasalahan untuk mencapai tujuan penelitian, dengan didasarkan pada pertimbangan adanya siswa yang diindikasi disleksia oleh guru dan memungkinkan untuk dilakukannya penelitian.

Penelitian ini akan dilaksanakan pada bulan Maret dan jadwal pelaksanaan penelitian disesuaikan dengan jadwal di SD N Sempu. Penelitian dilaksanakan sebanyak 20 sesi, dimana 5 sesi digunakan sebagai kondisi baseline awal (A1), 9 sesi digunakan sebagai kondisi intervensi (B2), dan 6 sesi digunakan sebagai kondisi baseline kedua (A2). Sedangkan, subjek dalam penelitian ini adalah anak yang terindikasi disleksia, kelas II SD N Sempu. Identitas subjek penelitian adalah sebagai berikut; (1) Inisial nama adalah GAS, (2) Jenis kelamin adalah laki-laki, (3) Agama adalah islam.

Penelitian ini menggunakan teknik analisis data statistik deskriptif. Statistik deskriptif merupakan teknik menganalisis data dengan mendeskripsikan atau 
menggambarkan data yang telah diperoleh sebagaimana adanya tanpa bermaksud membuat kesimpulan yang berlaku umum atau generalisasi (Sugiyono, 2012:207). Dalam penelitian yang menggunakan analisis statistik deskriptif data disajikan melalui tabel, grafik, diagram lingkaran, pictogram, pengkuran tendensi sentral dan perhitungan presentase. Penelitian ini menggunakan statistik deskriptif yang penyajian hasil datanya menggunakan tabel dan grafik untuk mengetahui perubahan kemampuan membaca pada subjek. Data hasil penelitian disajikan ke dalam grafik, alasannya karena dapat menunjang perubahan data pada setiap sesi serta menunjukkan besar kemampuan siswa dalam membaca pada kondisi baseline dan intervensi. Analisis data ini juga membandingkan antara kondisi baseline 1, intervensi, dan baseline 2 .

Selain grafik, analisi data yang digunakan dalam penelitian ini adalah analisis dalam kondisi dan analisis antar kondisi. Analisis perubahan dalam kondisi adalah analisis yang digunakan untuk menganalisis perubahan data dalam suatu kondisi, misal dalam kondisi baseline dan intervensi. Analisi dalam kondisi memiliki komponen (1) panjang kondisi, (2) kecenderungan arah, (3) kecenderungan stabilitas, (4) jejak data, (5) level stabilitas dan rentang, dan (6) perubahan level. Sunanto, Takeuchi, \& Nakata (2005:59) menjelaskan, langkah-langkah analisis dalam kondisi adalah sebagai berikut:

1. Menentukan panjang kondisi, yakni menunjukkan ada berapa sesi dalam kondisi tersebut.

2. Mengestimasikan kecenderungan arah, yakni digambarkan dengan garis lurus yang melintasi pada semua data dalam suatu kondisi. Dalam penelitian ini untuk mengetahui kecenderungan arah dengan menggunakan metode belah dua (splitmiddle).

3. Menentukan kecenderungan stabilitas.

4. Menentukan kecenderungan jejak data, yakni perubahan dari data satu ke data lain dalam suatu kondisi yang dapat ditunjukkan dari tiga kemungkinan yaitu, menaik, menurun, dan mendatar.

5. Menentukan level stabilitas dan rentang, yakni jarak antara data pertama dnegan data terakhir.

6. Menentukan level perubahan, yakni menunjjukan besarnya perubahan antara dua data. Tingkat perubahan data dalam suatu kondisi merupakan selisih antara data pertama dengan data terakhir.

Analisis selanjutnya yang digunakan dalam penelitian ini adalah analisis data antar kondisi. Analisis antar kondisi memiliki komponem yang meliputi (1) jumlah variabel yang di ubah, (2) perubahan kecenderungan dan efeknya, (3) perubahan kecenderungan stabilitas, (4) perubahan level, dan (5) data tumpang tindih (overlap). Sunanto, Takeuchi, \& Nakata (2005:59) menjelaskan, langkah-langkah analisis dalam kondisi adalah sebagai berikut:

1. Menentukan jumlah variabel yang diubah.

2. Menentukan perubahan kecenderungan arah dengan mengambil data pada analisis dalam kondisi di atas.

3. Menentukan perubahan kecenderungan stabilitas.

4. Menentukan level perubahan.

5. Menentukan overlap data kondisi baseline 1 (A1), intervensi (B), dan baseline 2 (A2).

Selain itu dalam mengalisis data hasil penelitian ini antara lain, menyusun data yang diperoleh ke dalam satuan-satuan. Data dari keseluruhan yang telah terkumpul melalui tes selanjutnya di olah untuk mengetahui hasil dari penelitian dan di analissi secara individu. Data kuantitatif yang diperoleh dari perhitungan skor kemampuan membaca pada awal sebelum di berikan perlakuan menggunakan Media SAKURA di analisis sehingga 
diperoleh hasil baseline 1. Skor kemampuan membaca pada tahap intervensi dan pengetesan akhir sesudah menggunakan Media SAKURA juga di analisis sehingga diperoleh skor intervensi dan baseline 2. Hasil skor pada baseline 1, intervensi, dan baseline 2 akan di analisis lagi dengan skor dan presentase, ekmudian peneliti akan mengkategorikan hasil terseut berdasarkan pedoman penilaian hasil tes menurut Purwanto (2013:102), yaitu:

$$
\mathrm{NP}=\mathrm{R} / \mathrm{SM} \times 100 \%
$$

Keterangan :

NP = Nilai persen yang dicari atau diharapkan

$\mathrm{R}=$ Skor mentah yang diperoleh

SM = Skor maksimal ideal dari tes yang bersangkutan

$100=$ Bilangan tetap

Kategori penilaian yang digunakan dalam penilaian ini juga menggunakan tabel pedoman penilaian menurut Purwanto, (2012:103), yaitu :

Tabel 1. Kategori Penilaian

\begin{tabular}{cc}
\hline $\begin{array}{c}\text { Tingkat } \\
\text { Penguasaan }(\%)\end{array}$ & Kategori/Predikat \\
\hline $86-100$ & Sangat Baik \\
\hline $76-85$ & Baik \\
\hline $60-75$ & Cukup \\
\hline $55-59$ & Kurang \\
\hline$\leq 54$ & Kurang Sekali \\
\hline
\end{tabular}

Setelah baseline 1 dan baseline 2 didapatkan skor dengan rumus di atas, maka untuk mengetahui pengaruh Media SAKURA terhadap kemampuan membaca dalam penelitian ini menggunakan statistik deskriptif yang penyajian datanya melalui tabel dan grafik.

\section{HASIL DAN PEMBAHASAN}

Pada penelitian ini langkah yang dilakukan untuk menguji hipotesis yaitu dengan menganalisis hasil data kondisi baseline 1 (A1), intervensi (B), baseline 2 (A2) yaitu dengan melakukan analisis dalam kondisi dan antar kondisi. Analisis data pada penelitian ini menggunakan statistik deskriptif dengan analisis grafik dan analisis data berdasarkan data individu. Analisis dalam kondisi dilakukan dengan menganalisis kondisi pada setiap kondisi penelitian yang berupa analisis panjang kondisi, kecenderungan arah, analisis stabilitas, jejak data, stabilitas, dan rentang data, serta analisis perubahan level. Analisis antar kondisi dalam penelitian ini yakni membandingkan kondisi pada kondisi satu dengan kondisi yang lainnya, dengan melakukan analisis antar kondisi peneliti dapat mengetahui seberapa besar pengaruh dari intervensi yang telah diterapkan. Analisis yang digunakan dalam analisis antar kondisi pada penelitian ini yaitu melakukan analisis banyaknya variabel yang di ubah, analisis perubahan kecenderungan arah, analisis perubahan stabilitas, analisis perubahan level, dan analisis data yang overlap. Pengujian dalam penelitian ini dilakukan dengan melihat penggunaan media SAKURA terhadap kemampuan membaca subjek sebelum dan sesudah diberikan treatment pada kondisi intervensi oleh peneliti. Hipotesis yang diajukan dalam penelitian ini adalah penggunaan media SAKURA untuk meningkatkan kemampuan membaca bagi anak disleksia.

Berdasarkan keseluruhan pengukuran yang telah dilakukan dalam penelitian ini untuk mengetahui serta memperjelas perkembangan dari seluruh hasil penelitian yang sudah dilakukan pada masing-masing kondisi pada tahap baseline 1 (A1), intervensi (B), dan baseline 2 (A2) dapat disajikan dalam tabel dan grafik berikut ini : 
Tabel 2. Perhitungan Skor Kemampuan Membaca

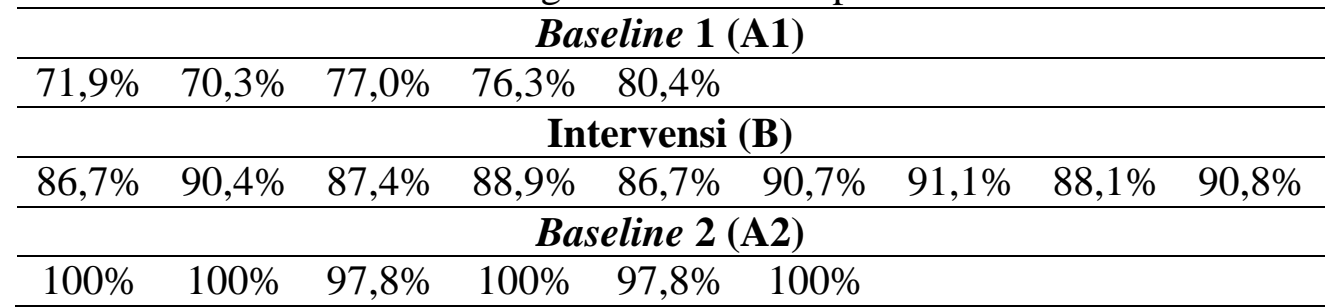

Tabel 2. perhitungan skor kemampuan membaca di atas merupakan perhitungan perolehan skor kemampuan membaca subjerk pada kondisi baseline 1 (A1), kondisi intervensi (B), dan kondisi baseline 2 (A2). Berdasarkan hasil penelitian diperoleh rata-rata skor akumulasi pada kondisi baseline 1 sebesar 75,2\%, kondisi intervensi sebesar 88,9\% dan kondisi baseline 2 sebesar 99,3\%. Data tersebut dapat memberikan kejelasan dan menunjukkan bahwa dengan dipergunakannya media SAKURA dapat memberi pengaruh dalam meningkatkan kemampuan membaca pada subjek karena adanya peningkatan pada data intervensi (B) dan baseline 2 (A2).

Berdasarkan data di atas, untuk memperjelas perolehan skor setiap kondisi selanjutnya data disajikan dalam bentuk grafik berikut :

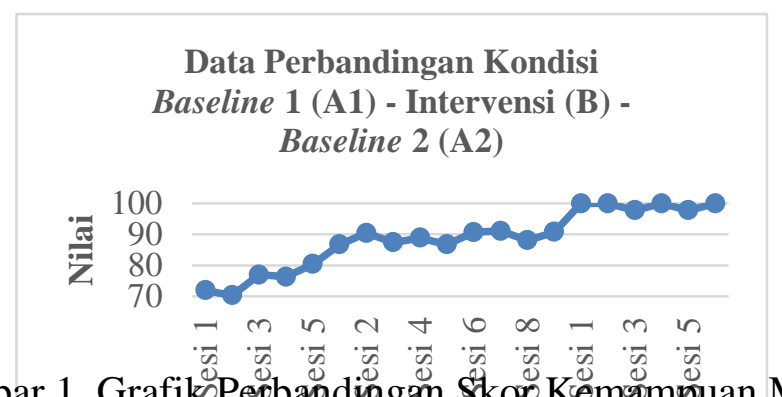

Gambar 1. GrafikPẹpandingam \$kơ Kemæmpuan Membaca Sesi

Keterangan grafik :

a. Garis vertikal memuat nilai kemampuan membaca.

b. Garis horizontal menggambarkan sesi dilakukan tes.

Data hasil penelitian ini kemudian di analisis dengan menggunakan analisis dalam kondisi dan antar kondisi.

\section{Analisis Dalam Kondisi}

Analisis dalam kondisi merupakan analisis yang dilakukan pada perubahan data pada kondisi tertentu. Kondisi penelitian yang dimaksdu dalam penelitian ini adalah kondisi baseline 1 (A1), kondisi intervensi (B), dan kondisi baseline 2 (A2). Sedangkan kondisi yang akan di analisis dalam penelitian ini adalah kondisi kemampuan subjek dalam membaca. Berikut ini adalah hasil analisis dalam kondisi pada penelitian ini :

Tabel 3. Analisis Dalam Kondisi

\begin{tabular}{lccc}
\hline \multicolumn{1}{c}{ Kondisi } & $\begin{array}{c}\text { Baseline 1 } \\
(\mathbf{A 1})\end{array}$ & $\begin{array}{c}\text { Intervensi } \\
\text { (B) }\end{array}$ & $\begin{array}{c}\text { Baseline 2 } \\
\text { (A2) }\end{array}$ \\
\hline 1.Panjang kondisi & 5 & 9 & 6 \\
\hline $\begin{array}{l}\text { 2. Estimasi } \\
\text { Kecenderungan }\end{array}$ & & & - \\
$\quad$ Arah & $(+)$ & $(+)$ & $(=)$ \\
\hline $\begin{array}{l}\text { 3. Kecenderungan } \\
\text { Stabilitas }\end{array}$ & $\begin{array}{c}\text { Stabil } \\
(100 \%)\end{array}$ & $\begin{array}{c}\text { Stabil } \\
(100 \%)\end{array}$ & $\begin{array}{c}\text { Stabil } \\
(100 \%)\end{array}$ \\
\hline
\end{tabular}




\begin{tabular}{lccc}
\hline 4.Jejak Data & & & \\
\cline { 3 - 4 } & & & \\
\hline 5.Level Stabilitas & Stabil & Stabil & Stabil \\
dan Rentang & $(69,2-81,2)$ & $(88,9-$ & $(91,8-$ \\
& & $95,7)$ & $106,8)$ \\
\hline 6. Perubahan Level & $80,4-71,9$ & $90,8-$ & $100-100$ \\
& $+8,5$ & 86,7 & $=0$ \\
& & $+4,1$ &
\end{tabular}

Berdasarkan tabel 3. analisis dalam kondisi di atas meunjukkan analisis dalam kondisi, diketahui bahwa panjang kondisi baseline $1=5$ dengan maksdu pada baseline 1 terdapat 5 sesi pertemuan, intervensi $=9$ yang berarti terdapat 9 sesi pemberian perilaku, dan baseline $2=6$ menunjukkan adanya 6 sesi pertemuan. Hasil estimasi kecenderungan arah memberikan keterangan bahwa kecenderungan perkembangan kemampuan membaca dari sesi awal hingga sesi terakhir pada setiap kondisi cenderung menaik. Kecenderungan kondisi baseline 1 dan intervensi mengalami penngkatan, sedangkan pada kondisi baseline 2 cenderung stabil.

Kecenderungan stabilitas, untuk kondisi baseline $1(\mathrm{~A} 1)=$ stabil, intervensi $(\mathrm{B})=$ stabil, dan baseline 2 (A2) = stabil. Kondisi baseline 1, intervensi, dan baseline 2 memiliki tingkat stabilitas sebesar $100 \%$ yang berarti bahwa tingkat kecenderungan stabilitasnya adalah stabil. Oleh karena itu, pada masing-masing kondisi menerangkan bahwa rentang data yang cenderung kecil atau tingkat variasi rendah. Kondisi kecenderungan data sama halnya dengan menentukan kondisi kecenderungan arah, sehingga data yang ada pada kondisi kecenderungan jejak data sama dengan data pada kondisi kecenderungan arah. Jejak data cenderung menaik pada kondisi baseline 1 (A) dan kondisi intervensi, sedangkan untuk kondisi baseline 2 jejak data stabil.

Level stabilitas dan rentang ditentukan dengan cara mengambil nilai terkecil dan terbesar yang diperoleh pada setiap kondisi. Level stabilitas untuk baseline 1 (A1) stabil dengan rentang 69,2 - 81,2 yang berarti rentang data pada kondisi baseline 1 antara nilai 69,2 hingga 81,2. Kondisi intervensi (B) stabil dengan rentang 82,1 - 95,7, sedangkan baseline 2 (A2) stabil dengan rentang data antara 91,8 - 106,8. Adapun perubahan level dilakukan dengan cara menghitung selisih data yang terbesar dan data terkecil dari setiap kondisi. Tanda (+) menunjukkan adanya perubahan yang membaik, tanda (-) menunjukkan perubahan memburuk, dan $(=)$ menunjukkan tidak ada perubahan. Lebel perubahan berdasarkan hasil analisis kondisi baseline $1(\mathrm{~A} 1)=+8,5$ yang artinya menunjukkan kondisi membaik sebesar 8,5 . Kondisi intervensi $(B)=+4,1$ menunjukkan data membaik sebesar 4,1, sedangkan pada kondisi baseline $2(\mathrm{~A} 2)=0$, menunjukkan bahwa data pada fase baseline 2 tidak ada perubahan atau cenderung stabil.

\section{Analisis Antar Kondisi}

Analisis antar kondisi dilakukan dengan membandingkan kondisi pada satu kondisi dengan kondisi yang lain. Berikut mrupakan hasil analisis antar kondisi hasil penelitian terhadap kemampuan membaca :

Tabel 4. Analisis Antar Kondisi

\begin{tabular}{lcc}
\hline \multicolumn{1}{c}{ Perbandingan Kondisi } & $\begin{array}{c}\text { Intervensi (B)/ } \\
\text { Baseline 1 (A1) }\end{array}$ & $\begin{array}{c}\text { Baseline 2 (A2)/ } \\
\text { Intervensi (B) }\end{array}$ \\
\hline $\begin{array}{l}\text { 1. Jumlah Variabel yang } \\
\text { diubah }\end{array}$ & 1 & 1 \\
\hline 2. Perubahan Kecenderungan & & \\
\hline
\end{tabular}




\begin{tabular}{lcc}
\hline \multicolumn{1}{c}{ Arah dan efeknya } & $(+)(+)$ & $(+)(+)$ \\
\hline $\begin{array}{l}\text { 3. Perubahan Kecenderungan } \\
\text { Stabilitas }\end{array}$ & Stabil ke Stabil & Stabil ke Stabil \\
\hline $\begin{array}{l}80,4-86,7 \\
+6,3\end{array}$ & $\begin{array}{c}90,8-100 \\
+9,2\end{array}$ \\
\hline 5. Perubahan Level & $\frac{0}{9} \times 100 \%=0 \%$ & $\frac{0}{6} \times 100 \%=0 \%$
\end{tabular}

Berdasarkan data tabel di atas, dapat dijelaskan bahwa jumlah variabel yang diubah adalah satu, yaitu kondisi baseline 1 (A1) ke intervensi (B). Kemudian perubahan kecenderungan arah ditentukan dengan cara mengambil data pada analisis dalam kondisi dengan kecenderungan (naik, turun, dan tetap) hal ini dilakukan untuk melihat perubahan perilaku. Kecenderungan arah perubahan yang terjadi pada subjek yang di teliti menjelaskan bahwa perubahan kecenderungan pada kondisi baseline 1 (A1) dengan intervensi (B) yakni menaik dan menaik, yang artinya kondisi baseline 1 (A1) dengan intervensi (B) kondisi kembali meningkat setelah intervensi dilakukan. Perbandingan antara kondisi intervensi (B) dengan kondisi baseline 2 (A2) yakni tetap dan menaik, yang artinya menunjukkan kondisi tetap setelah pemberian intervensi dan cenderung menaik di banding kondisi baseline 1 (A1).

Terdapat seorang siswa kelas II SD yang terindikasi disleksia di salah satu sekolah inklusi di Sleman yaitu SD Negeri Sempu. Anak yang terindikasi disleksia mengalami hambatan pada kemampuan membaca. Hal ini, tentu berdampak pada kemampuan yang lain seperti yang dijelaskan bahwa kesulitann membaca yang dialami anak akan berdampak pada kesulitan menulis, kondisi ini sering disebut dengan disleksia. Mulyadi (2010:154) menjelaskan bahwa disleksia merupakan kesulitan membaca, mengeja, menulis serta kesulitan dalam mengartikan atau mengenali struktur kata yang memberikan efek terhadap proses belajar. Padahal Lerner dalam Abdurrahman (2012:157) menjelaskan, bahwa kemampuan membaca digunakan sebagai dasar untuk menguasai berbagai bidang studi. Jika pada anak usia sekolah permulaan tidak segera memiliki kemampuan membaca, maka akan mengalami banyak kesulitan dalam mempelajari berbagai bidang studi pada kelas-kelas berikutnya. Oleh karena itu, anak harus belajar membaca agar dapat menguasai berbagai bidang studi.

Upaya perlakuan atau intervensi dalam penelitian ini berupa penggunaan media SAKURA berbasis multisensori untuk meningkatkan kemampuan membaca bagi anak disleksia. Tujuan penelitian ini untuk menguji efektivitas media SAKURA berbasis multisensori terhadap kemampuan membaca anak disleksia. Melalui media SAKURA ini subjek dapat berlatih untuk membedakan huruf secara nyata dengan memegang dan meilhat secara langusng huruf-huruf alfabet. Sehingga, subjek mampu untuk melafalkan, menyusun, dan menulis huruf. Kemudian, subjek juga diharapkan mampu untuk melafalkan, menyusun, dan menulis suku kata. Serta subjek juga diharapkan mampu untuk melafalkan, menyusun, dan menulis kata.

Perlakuan dalam penelitia ini menggunakan media SAKURA berbasis multisensori yang dilakukan sebanyak 9 sesi. Berdasarkan hasil pengolahan dan analisis data yang telah dilakuka, dapat menunjukkan bahwa intervensi menggunakan media SAKURA efektif dalam meingkatkan kemampuan membaca pada subjek yang diteliti. Hal ini dapat ditunjukan pada perkembangan kemampuan membaca subjek dalam melafalkan, menyusun, dan menulis huruf, suku kata, kata.

Pada kondisi awal subjek yang senelumnya banyak mengalami kesalahan dalam melafalkan, menyusun, dan menulis huruf, suku kata, kata. Setelah diberikan intervensi 
subjek mampu melafalkan, menyusun, dan menulis huruf, suku kata, kata dibandingkan pada kemampuan awal subjek. Sebelum diberi intervensi subjek mengalami kesulitan hampir pada semua indikator. Namun, setelah diberi intervensi kemampuan membaca subjek semakin membaik.

Peningkatan kemampuan membaca pada subjek dapat terlihat pada sesi pertama intervensi dan pada sesi kedua yang mengalami peningkatan. Meski pada sesi ketiga mengalami penurunan, namun pada sesi ketiga hingga sesi ke tujuh subjek terlihat mengalami peningkatan terus tetapi subjek kembali mengalami penurunan sedikit pada sesi ke delapan dan kembalik mengalami peningkatan pada sesi kesembilan. Sedangkan, pada kondisi baseline 2 atau setelah dilakukannya intervensi nilai tes mengalami penurunan pada sesi tiga dan lima namun kemabil naik seperti sesi pertama dan sesi lainnya.

Melalui media SAKURA ini subjek sangat antusias dalam mengenal dan membedakan huruf alfabet, karena media SAKURA yang dirancang sedemikian rupa untuk menarik minat anak agar mau belajar mengenal huruf dan mengasah kemampuan membacanya secara bertahap dari huruf, suku kata dan kata. Subjek pun terlihat tidak pernah bosan untuk bermain media SAKURA, hal ini tentu akan merangsang kemampuan membaca subjek jika sering dilakukan treartment menggunakan media SAKURA.

Selama pelaksanaan pada setiap kondisi, terdapat adanya penurunan nilai yang diperoleh. Menurut pengamatan peneliti pada setiap sesi, hal ini terjadi karena tingkat kesulitan soal yang diteskan meningkat dan subjek sendiri memiliki kesulitan seperti, kesulitan memahami dan mengingat perintah yang panjang atau mudah lupa, sulit menggabungkan bunyi huruf, masih agak sulit membedakan huruf yang sama, sangat lambat dalam menulis karena masih mengingat-ingat huruf yang mana yang harus ditulis. Hal ini sesuai dengan ciri-ciri anak dislesksia yang dijelaskan Aphroditta (2014:66) seperti; (1) membaca secara terbalik tulisan yang dibaca seperti: duku dibaca kudu, d dibaca b, p dibaca q, dan sebagainya, (2) menulis huruf secara terbalik, (3) mengalami kesulitan dalam menyebutkan kembali informasi yang diberikan secara lisan, (4) kualitas tulisan buruk, karakter huruf yang ditulis tidak jelas, (5) sulit dalam mengikuti perintah yang diberikan secara lisan, (6) mengalami kesulitan dalam menentukan arah kiri dan kanan, (7) mengalami kesulitan dalam memahami dan mengingat cerita yang baru dibaca, (8) mengalami kesulitan dalam mengenal bentuk huruf dan mengucapkan bunyu huruf, (9) mengalami kesulitan dalam menggabungkan bunyi huruf menjadi kata yang berarti, serta (10) sangat lambat dalam membaca karena kesulitan dalam mengenal huruf, mengingat bunyi huruf dan menggabungkan bunyi huruf menjadi kata yang berarti.

Kesulitan yang dialami subjek tentu jelas terlihat pada hasil tes kondisi baseline 1 yang belum diberi perlakuan. Pada tes baseline 1 sesi pertama didapatkan nilai rerata sebesar 71,9. Pada tes baseline 1 sesi kedua didapatkan nilai rerata sebesar 70,3. Pada tes baseline 1 sesi ketiga didapatkan nilai rerata sebesar 77,0. Pada tes baseline 1 sesi keempat didapatkan nilai rerata sebesar 76,3. Dan pada tes baseline 1 sesi pertama didapatkan nilai rerata sebesar 80,4. Berdasarkan hasil tes yang telah dikerjakan oleh subjek pada baseline 1, nilai yang diperoleh subjek dari sesi pertama hingga sesi kelima mengalami kenaikan dan penurunan. Pada sesi kelima fase baseline 1 dihentikan karena hasil yang dicapai subjek telah stabil. Analisis aktivitas pada kondisi baseline 1 ini, subjek mampu melafalkan secara mandiri semua soal baik huruf, suku kata maupun kata dengan baik meski ada beberapa yang mengalami kesulitan yakni dalam melafalkan kata yang struktur hurufnya sulit. Sedangkan untuk menyusun huruf, suku kata dan kata 
subjek dapat melakukannya secara mandiri, meski awalnya masih bingung dalam memahami instruksi peneliti. Namun, untuk indikator menulis huruf, suku kata dan kata subjek banyak mengalami kesulitan.

Hasil yang didapatkan pada kondisi baseline 1 ini murni kemampuan subjek, karena belum dilakukannya intervensi. Sehingga, pada kondisi intervensi dapat dilihat hasil tes subjek mengalami peningkatan. Pada tes intervensi sesi pertama didapatkan nilai rerata sebesar 86,7. Pada tes intervensi sesi kedua didapatkan nilai rerata sebesar 90,4. Pada tes intervensi sesi ketiga didapatkan nilai rerata sebesar 87,4. Pada tes intervensi sesi keempat didapatkan nilai rerata sebesar 88,9. Pada tes intervensi sesi kelima didapatkan nilai rerata sebesar 86,7. Pada tes intervensi sesi keenam didapatkan nilai rerata sebesar 90,7. Pada tes intervensi sesi ketujuh didapatkan nilai rerata sebesar 91,1. Pada tes intervensi sesi kedelapan didapatkan nilai rerata sebesar 88,1. Dan pada tes intervensi sesi kesembilan didapatkan nilai rerata sebesar 90,8. Berdasarkan data di atas dapat diperhatikan bahwa ketercapaian subjek dalam menggunakan medi SAKURA sudah baik, di mana subjek mampu menyelesaikan tes dengan skor 100 meski ada beberapa tes yang tidak mendapatkan skor 100 tetapi hampir mendekati 100. Ketertarikan subjek dalam menggunakan media SAKURA juga baik, selama pembelajaran dengan menggunakan media SAKURA tidak menunjukkan sikap bosan atau menolak media tersebut. Salama menggunakan media SAKURA subjek dapat malaflkan, menyusun, menulis huruf, suku kata maupun kata dengan baik.

Setelah dilakukannya perlakukan, hasil yang didapatkan meningkat yang berarti kemampuan membaca subjek juga meningkat. Sehingga, dilakukan tes kembali pada kondisi baseline 2 tanpa menggunakan perlakuan juga didapatkan hasil yang meningkat. Pada tes baseline 2 sesi pertama didapatkan nilai rerata sebesar 100. Pada tes baseline 2 sesi kedua didapatkan nilai rerata sebesar 100. Pada tes baseline 2 sesi ketiga didapatkan nilai rerata sebesar 97,8. Pada tes baseline 2 sesi keempat didapatkan nilai rerata sebesar 100. Pada tes baseline 2 sesi kelima didapatkan nilai rerata sebesar 97,8. Dan pada tes baseline 2 sesi keenam didapatkan nilai rerata sebesar 100. Berdasarkan soal yang telah dikerjakan oleh subjek pada baseline 2, nilai yang diperoleh subjek dari sesi pertama hingga sesi keenam mengalami kenaikan dan penurunan. Analisis aktivitas pada kondisi baseline 2 ini, subjek mampu melafalkan secara mandiri semua soal baik huruf, suku kata maupun kata dengan baik. Sedangkan untuk menyusun huruf, suku kata dan kata subjek juga dapat melakukannya secara mandiri. Namun, menulis huruf, suku kata dan kata subjek banyak mengalami peningkatan.

Data hasil penelitian menunjuan adanya perubahan kemampuan memahami dari kondisi ke kondisi dalam penelitian ini. Kondisi baseline 1 kemampuan membaca subjek masih dalam kategori cukup. Setelah di berikan intervensi berupa penggunaan media SAKURA, kemampuan subjek mengalami peningkatan sampai pada kondisi baseline 2 meningkat dalam kategori sangat baik. Data hasil penelitian juga menunjukkan bahwa tidak terdapat tumpang tindih data antarkondisi baseline 1 ke kondisi intervensi (0\%). Hal ini menunjukkan bahwa penerapan media SAKURA efektif segera memberikan pengaruh pada kemampuan membaca subjek. Sedangkan hasil data intervensi ke baseline 2 juga tidak terdapat data yang tumpang tindih (0\%).

Berdasarkan hasil pemaparan di atas, menunjukkan bahwa penggunaan media SAKURA mempunyai pengaruh dalam meningkatkan kemampuan memahami siswa terindikasi disleksia kelas II SD Negeri Sempu. Hal ini didukung dengan adanya peningkatan kemampuan membaca siswa yang terindikasi disleksia yang ditandai dengan meningkatya presentase nilai hasil tes membaca dari kondisi ke kondisi. Menurut Sunanto, Takeuchi, \& Nakata (2005: 116) menyatakan bahwa semakin kecil 
presentase overlap makin baik pengaruh intervensi terhadap target behavior. Hasil penelitian Rofiah \& Sukma (2017) bahwa dengan menggunakan media SAKURA ini terlihat kemampuan membaca siswa dapat meningkat. Berdasarkan pendapat ahli dan hasil penelitian yang relevan dapat disimpulkan bahwa media teka-teki bergambar berpengaruh secara efektif dalam meningkatkan kemampuan membaca siswa terindikasi disleksia kelas II SD di SD Negeri Sempu.

\section{SIMPULAN}

Berdasarkan hasil penelitian dan pembahasan dapat disimpulkan bahwa penerapan media SAKURA berbasis multisensori efektif meningkatkan kemampuan membaca bagi anak disleksia. Hal ini dapat dibuktikan dengan adanya peningkatan presentase ketercapaian subjek pada saat diberikan perlakuan. Pada penelitian ini subjek (GAS) mendapatkan mean level meningkat dari 75,2 pada kondisi baseline 1 (A1) menjadi 88,9 pada kondisi intervensi (B), dan 99,3 pada kondisi baseline 2 (A2). Hal ini didukung dengan presentase overlap yang rendah. Persentase overlap antar kondisi baseline 1 dan kondisi intervensi yaitu $0 \%$ dan kondisi intervensi dengan baseline 2 yaitu $0 \%$.

\section{DAFTAR PUSTAKA}

Abdurrahman, Mkulyono. 2012. Anak Berkesulitan Belajar: Teori, Diagnosis, dan Remediasinya. Jakarta : Rineka Cipta.

Aphroditta, M. 2014. Panduan Orang Tua \& Guru untuk Anak dengan Disleksia (Kesulitan Membaca). Yogyakarta : Javalitera.

Jamaris, Martini. 2015. Kesulitasn Belajar : Perspektif, Asesmen, dan Penanggulangannya. Bogor: Ghalia Indonesia.

Mulyadi. 2010. Diagnosis Kesulitan Belajar dan Bimbingan terhadap Kesulitan Belajar Khusus. Yogyakarta : Nuha Litera.

Praptiningrum. Nurdayati., \& Purwandari. 2009. Metode Multisensori untuk Mengembangkan Kemampuan Membaca Anak Disleksia Di SD Inklusi. Jurnal Penelitian Ilmu Pendidikan. Vol 02 No.2.

Purwanto, Ngalim. 2013. Prinsip-Prinsip dan Teknik Evaluasi pengajaran. Bandung:Remaja rosdakarya.

Rofiah, Nurul Hidayati., \& Sukma, Hanum Hanifah. 2017. Alat Peraga Berbasis Literasi untuk Anak Disleksia. Laporan Penelitian. Tidak Diterbitkan.

Sadiman, Arief S., dkk. 2014. Media Pendidikan: Pengertian, Pengembangan, dan Pemanfaatannya. Jakarta: PT Raja Grafindo Persada.

Sanjaya, Wina. 2015. Perencanaan dan Desain Sistem Pembelajaran. Jakarta: Prenadamedia.

Sunanto, Juang., Koji Takeuchi., \& Hideo Nakata. 2005. Pengantar Penelitian dengan Subyek Tunggal. Jepang: CRICED University of Tsukuba.

Sugiyono. 2016. Metode Penelitian Kuantitatif, Kualitatif, dan R\&D. Bandung : Alfabeta. Wood. Derek., dkk. 2014. Kiat Mengatasi Gangguan Belajar. Yogyakarta : Katahati. 